\title{
GRAVITY CENTERS OF CENTRAL EUROPEAN URBAN NETWORK - GLOBAL EMBEDDEDNESS BASED ON ADVANCED PRODUCER SERVICES
}

\author{
Katalin DÖBRÖNTE \\ åötvös Lóránd University, Earth Studies Doctoral School, dobronte.katalin@t-online.hu \\ Cite this article: Döbrönte, K. (2016). Gravity Centers of Central European Urban Network - Global \\ Embeddedness Based on Advanced Producer Services. Deturope, 8, 3: 53-71
}

\begin{abstract}
The focus of the paper is on how Central-European cities can join the global urban network by taking part in offering high level business services for multinational companies. Companies offering these high level business services are multinational companies themselves, which locate their offices in the production and service-providing centers. New centralities and marginalities occur, and a key question how the fragmented Central European urban structure mainly characterised by small cities is affected by these changes, which cities became global cities, and which cities can be integrated in the urban network on a regional level. The hypothesis is justified by the examinations, mainly the integration of capital cities can be witnessed. Primary gravity centers are Warsaw and Vienna, besides Prague and Budapest can be identified as global cities of the region. The Central-European space is connected as a macro-region, all capital cities are on the map of examination, no new periphery occurs on macro level. The role of big cities apart from capital cities is in strong correlation with the relevant country's urban network, with its mono- vs polycentric type of organization.
\end{abstract}

Keywords: global urban structure, Central Europe, advanced producer services

\section{INTRODUCTION}

According to Hall (Hall, 1990) the whole European urban structure was influenced by the changes took place in Central and Eastern Europe in 1989-90, and especially Berlin and Vienna could get back their role and nodes of international flows and traffic again, and could become thus more attractive locations for advanced producer services as well. This is also true for Warsaw, Budapest and Prague. According to Kunzmann (Kunzmann et al., 1996) the development of cities on the peripheries could restructure the spatial structure of the European urban network.

Present paper focuses on the Central European urban network, and studies how far it could got integrated to the global urban structure based on location strategies of advanced producer services as indicator. 
There has been a shift in the approach of the development of the European urban network in the past 10 years. Previously the European Spatial Development Perspective defined the directions for development of European urban structure. It was based on the polycentric approach, and aimed at developing cities in order to form a counterweight to the cities of Pentagon. (European Commission, 1999). However, according to the development processes of the years after 2000, globalization process came to the front also in the urban structure policy, and a shift occurred in European Union policy: development is focused on the significant metropolitan regions, where economic and innovation capacities are concentrated. So the metropolitan regions got integrated into the global urban network, and the polycentric policy was shifted to the level of mid and small sized cities. (European Commission, 2007) It became clear that a European urban network does not exist in itself, only as part of the global urban network. Certain European large cities become key actors in international economic processes and thus they are linked to global processes. The main focus of this paper, how far the Central European cities can become actors in these processes, and which cities these are.

The paper deals with the cities of Hungary, Slovakia, Poland, Czech Republic, Slovenia, Romania, Bulgaria, Croatia, Serbia, Bosnia-Herzegovina, Macedonia, Kosovo and Montenegro as parts of Central European urban network. Examination of Austrian cities is also included for reasons of comparison, as they are geographically in the same space, however with different development opportunities.

First a justification for the relevance of the topic is given, and theoretical embeddedness is offered. The paper is based on Sassen's global city notion, and further on builds on Sassen's New Economy and on the work of Taylor and the Global and World City Research Group and Network (GAWC). They already conducted several researches based on the advanced producer services on global level, however Central European space did not form part of their studies.

\section{OBJECTIVES AND METHODS}

The development of a transnational urban network can be witnessed in the last 30-35 years, where the nodes are important cities of global economy. These cities have a key role in the international network flows of capital, information and labour force as nodal points. These processes strengthen further the position of these cities. There is a shift in the key relations and interactions of cities. As Friedmann states (1986), it is not the strong relationships with 
the hinterland any more that determines the position of the global cities, but the speed and depth of integration of these cities into different flows (De Vos et al., 2012). Here the dichotomy of Friedmann's world city (1986) and Sassen's global city (1991) notion meets. The question is whether world cities or global cities are the key actors when examining the advanced producer services.

De Vos (De Vos et al., 2012) offers the comparison of the world city and global city notions, and while the network of world cities redesigns the traditional centrum - periphery patterns in the world economy, the global urban network can exceed these limits. While in case of world cities the main actors are the multinational companies without limiting their type of activity, and function as a power center, „container”, in case of global cities main actors are the specialized business service providers and the central cities can be defined as servers of global capital. As a result the centrum - periphery dichotomy transforms and the new geography of central and marginal places emerges. Global cities are characteristically not embedded in their region, main focuses of relationships fall out of the physically surrounding geographical space. In case of the global cities we can talk about functional centrality contrary to the central place theory of Christaller (De Vos et al., 2012).

Study of global cities goes back to Hall's world city concept in 1966 and to Friedmann's and Wolff's world city notion in 1982. Hall defines world cities based on their functions and accordingly these cities are centers of national and international political power, centers of governmental, public administration institutions, and centers of national, international and generally speaking of economic activities. Friedmann and Wolff make a step forward, and they mean that world cities are characterised by the dominance of financial and service sector within economy. These cities are closely interrelated via communication technologies and financial operations, and practice a worldwide control over market expansion. (Hall, 1966, Friedmann et al., 1982)

Taylor's world city concept builds on Wallerstein's world-system theory in a sense that a world city for Wallerstein is a historically defined and evolving system that already determines a city's position in the world-system.

Sassen was the first to word the notion of global city in 1991 in her work related to the New Economy. As contrary to Taylor she votes for the notion of the global city instead of world city, however using the same argument. Their reasoning is in line, central cities have global function, however, no historical determination is, however, at stake. Of course there 
are global cities that are world cities at the same time and vice versa. Global city as a notion offers the definition of those cities that have a strategic role within the global urban network.

Accordingly also world economic processes have become more intensive with the development of communication technology and with the strengthening of liquidity and mobility of capital, but first the main actors were state actors. It was with the deregulation of markets and the appearance and spread of multinational companies that world economic process developed into global economic processes.

Overrunning the central place theory - that considered central place as a decision-making center with a strong interaction with its region, hinterland - a new approach occurs: main interactions take place between global cities and not with the surroundings.

Sassen defined in her New Economy advanced producer service providers as key actors in the organization of the global economy. Production is concentrated in the biggest cities, and location of advanced producer services is linked to them. As producer companies increased number of sites, business service companies adapted their location strategies and followed the producers in order to maintain business relations. In fact the emergence of the multinational network of advanced producer services was a reply to the strategic decisions of producer companies, to the changes of their location strategies. And thus arriving to the point, the activity of advanced producer services formed a global urban network, comprising activities like global advertising campaigns, system of contracting, electronic communication and personal relations among the sites of the business service provider. (Taylor, 2004, Taylor, 2012)

According to Sassen (1991) several factors influenced the model of global city. The ever stronger geographical spread of economic activities strengthened the role of central organizational functions. The broader spread are the activities of the multinational companies geographically, the more complex are the central strategic functions. The scale and complexity of these functions can reach such an extent that producer companies tend to outsource these functions to specialized service providers. Thus besides the seat of the multinationals, the advanced service providers also gain key positions as handling strategic functions of production companies. It has an even larger emphasis in cases where companies are actors in the global markets and their activities exceed routine activities. It is characteristic that more and more multinational buys advanced business services from specialized service providers. As a result of this process a high concentration of business service providers mean an important information basis and economic power. As production activities are not 
necessarily concentrated physically, and are carried out on sites with different comparative advantages, real concentration is realized by the advanced business service providers that always concentrate locations also physically. The statement the more multinational company seat a city comprises the bigger economic role it has in the world economy was clearly true before, however the picture is more diversified today. The statement is still valid in many places, however in countries with a developed infrastructure, producer companies can apply a more diversified location strategy for their production activities, and production site and business center does not necessarily match. The centralization of specialized business service providers results in a new type of geographical concentration. The role of the advanced service providers - which themselves are multinational companies, is to realize an even stronger concentration, to carry out strategic company functions while adapting to the spatial dispersal of economic processes. As a working environment for these business services the different countries operate different legal systems, accounting systems, advertising culture, etc. Thus processes reach such complexity that the producer companies are themselves interested in outsourcing these functions and save resources for the core production activities (Sassen, 2005).

Methodologically speaking study of the cooperation of the global urban network based on advanced producer services is only indirectly feasible. In case of studying networks, two levels are at hand: the level of the nodal points, the cities, and the level of cooperation, the interactions among the nodes. In case of the advanced service providers a third level appears as well. The services take place in the cities, which is the middle level. The cities provide the site for the producer companies' activity, to which the advance producer services are linked, and the activity of the service providers is also realized on the premises of the city. However, the relations themselves do not take place among cities, but happens on the sub-city level, the business services are in cooperation with each other. And as a third point, the network itself works on a supra-city level, among the sites of the business service providers, and the seat of these management companies where the decisions are taken. Thus not the cities themselves are the decision-making centers, but it takes place on the supra-city level, in the multinational companies, which are also responsible for the interactions in the network. (Taylor et al., 2012)

Location and space is a central notion in the operation of the global economy further on. In the 1980s when the globalization of the economy was in the forefront, emphasis was put on the hypermobility of capital and the globalization of communication, and at the same time the importance of space and place became neutral (Sassen, 2000). However, the last decades 
proved that global economic processes also take place in space, and need resources that are not hypermobile, but embedded in place. Thus the role of space, and first of all, the value of cities increased again, and the geography of strategic places, the new geography of centrality became highlighted. According to the new geography of central places, global economic processes are materialized as well, and the centers of these activities are usually the global cities. Globally integrated organisations also need a central location, where the activity itself takes place. As an example, information industry also needs significant infrastructure and their strategic nodes are where facilities are concentrated. It is also valid for other industries where majority of activities take place in the electronic space, like in case of finance. This approach leads to the conclusion that those cities emerge as nodal points that concentrate on services based on communication technologies to a large extent (Derudder et al., 2012).

Global economy results in new global and regional hierarchies of cities, and cities that cannot join the global processes get to the periphery. Former production centers and ports are crowded out and got marginal. (Sassen, 2008) Our main question is whether Central European urban network can become part of these processes or it gets to the periphery.

The most comprehensive study of the global urban network processes based on the advanced producer services was carried out by Taylor and co-researchers in the frame of the Global and World City Research Group and Network (GAWC). Their aim was to identify those global cities that base position on corporate services. The research unit is the service provider and study focuses on the presence of these business services in cities. Studying networks and interactions shows position of a city based on a certain type of specialized service (e.g. accounting, legal, marketing services, etc.), and by weighting them, relative position of a city in the global urban network.

Not a large number of cities in Central Europe have global role, really some capitals have the potential for joining the global economic processes. Also Central European urban structure is not an integrated one, national networks are not linked. As a result of the historic development of cities in Central Europe the level of urbanization is lower than in Western Europe. Industrialization and rise of middle class took place late, they could not enter the world commerce on the seas, lacked colonies, and their economies operated in the feudal system longer than in Western Europe. Still there are differences in this region as well, in Czech-Moravia and Upper-Silesia industrialization started relatively earlier, and thus the cities here could catch-up with development processes in Western-Europe better than the cities of Hungary, Slovakia, East-Poland, the Transylvanian part of Romania where 
urbanization started only in the 2 nd half of the 19 th century. Modernisation and development of the urban network in the Balkan countries only began after the 1st world war as a consequence of the continued presence of the feudal Turkish Empire. The emergence of the nation states in the region resulted countries with low number of inhabitants, and with relatively small cities considering number of population, and lack of mid-sized cities compared to Western Europe. Wars, also considering the world wars had a significant impact on these counties' territories, population and urban network, important changes, reorganizations took place. In the socialist era central state governance determined the development of cities overshadowing market processes. Quantitative city development took place as a contrary to quality development, the number of cities highly increased, however not all cities could fulfil all functions a city is expected to. During the 1990s the isolation of cities in the region ended, and integration with the European urban network was a real possibility for development. Favourable processes occurred, inflow of capital and technology, appearance of multinational companies, visits of foreign tourists in cities. As a consequence of late integration and underdeveloped infrastructure a strong city competition emerged for the resources and factors. Capitals had a real advantage in this city-competition which further strengthened the trait processes that concentrates modernization on a few number of nodes (Pounds, 2003).

\section{RESULTS}

Primarily capital cities could become part of the global structure, and capitals are overrepresented in the examination sample. However there are important differences among positions of different capital cities in the region. Referring back to Hall's (1990) statement, the absolute lead of Vienna is not underlined.

Derudder (Derudder et al., 2012) conducted a comparative research based on Taylor's and Alderson's previous findings regarding the global urban structure based on the one hand on the site location of multinational companies, and on the other hand on the locations of advanced producer services (Alderson et al., 2010) studied 6,308 cities and the sites of the 500 biggest multinational companies, while Taylor (Taylor et al., 2011) examined 175 advanced producer services in 525 cities. Nine Central European cities got on the map out of 130 significant cities: Budapest, Bucharest, Bratislava, Ljubljana, Prague, Sofia, Vienna, Warsaw and Zagreb, all of them capitals. According to the findings three of them, Prague, 
Warsaw and Vienna have the strongest embeddedness in both corporate networks. Budapest and Bucharest are embedded in the network of business service providers. Sofia, Ljubljana, Zagreb and Bratislava are neither global, nor world cities, these capitals have only regional scopes (De Vos et al., 2012).

The results of the present study show correlation with these results. According to the findings of the study, lead cities in Central Europe are Warsaw and Vienna based on the presence and interactions of advanced producer services. It is important however, no overall primarily role of Vienna can be underlined, on the contrary, Warsaw has a more significant role than Vienna, however the gap is moderate. Among leading capitals we have to mention Budapest, Prague and Bucharest on the second level. However comparing networking among main cities in the region we can state there are only four competitive capitals in the studies sample, Vienna, Warsaw, Prague and Budapest.

All the West-Balkan capitals are on the map for the full service type of consultancy companies. It is a very important fact, as this position ensures the involvement of the Western Balkans to the European urban structure, and thus keeping it integrated, and not allowing becoming a new marginality.

As regards cities outside capitals, 41 cities are involved besides the 14 capitals, and there are 15 cities involved with less than 100.000 inhabitants. Although the capital cities are in the best position for integration to the global urban network, their opportunities are not exclusive. Although not on a global level, but rather regional level, other cities than capital cities can join the structure, in certain countries even small cities with inhabitant numbers below 100.000 .

Location strategies of the consultancy companies are in line with the urban structure of all countries. All location decisions reflect whether the said country has a polycentric or monocentric structure. In this respect the most cities with locations are involved in Austria, but also the Czech Republic and Poland shows its polycentric structure through the location strategies of business service providers. In this respect Hungary and Serbia shows the most monocentric structures.

Full service companies are present in all countries and all capitals with an approach of total market coverage, which is also important in not getting excluded from global processes. The real question is the location strategies of the strategic consultancy companies, these are which can really offer positions for cities in the region. 
As a consequence we can state, a clear integration to the global urban structure can be witnessed in case of Vienna, Warsaw, Prague, Budapest, and maybe Bucharest.

\section{DISCUSSION}

Altogether 16 countries are involved in the study of Central-European space, where 105 cities are present with an inhabitant number above 100.000 (Tab. 1.). As a characteristic of the Central European region the population of the biggest city, in fact the capital city does not exceed 500.000 in seven countries, and in the domain $100.000-500.000$ no other (- or maximum one other city) occurs. In the other nine studied countries there is only one city, the capital - with the exception of Poland - where population exceeds 500.000, in case of seven capital cities more than one million. It's only Poland where five big cities have inhabitants more than 500.000, and it is only in Poland and Romania where a two digit number of cities exceeds the inhabitant number of 100.000 . These data show expressively the scale of cities in Central Europe, its fragmented characteristic which occurs as a disadvantage in integration into global networking systems.

Table 1 Research space

\begin{tabular}{|c|c|c|c|c|}
\hline Countries & $\begin{array}{c}\text { Number of cities } \\
\text { with more than } \\
\text { one-million } \\
\text { inhabitants } \\
\end{array}$ & $\begin{array}{c}\text { Number of cities with } \\
500.000-1 \text { million } \\
\text { inhabitants }\end{array}$ & $\begin{array}{c}\text { Number of cities } \\
\text { with } 100.000- \\
500.000 \\
\text { inhabitants } \\
\end{array}$ & Summa \\
\hline Austria & 1 & 0 & 4 & 5 \\
\hline Hungary & 1 & 0 & 7 & 8 \\
\hline Czech Republic & 1 & 0 & 5 & 6 \\
\hline Slovakia & 0 & 0 & 2 & 2 \\
\hline Poland & 1 & 4 & 34 & 39 \\
\hline Romania & 1 & 0 & 19 & 20 \\
\hline Bulgaria & 1 & 0 & 6 & 7 \\
\hline Moldova & 0 & 1 & 2 & 3 \\
\hline Slovenia & 0 & 0 & 1 & 1 \\
\hline Croatia & 0 & 1 & 2 & 3 \\
\hline Bosnia - Herzegovina & 0 & 0 & 2 & 2 \\
\hline Serbia & 1 & 0 & 3 & 4 \\
\hline Kosovo & 0 & 0 & 1 & 1 \\
\hline Montenegro & 0 & 0 & 1 & 1 \\
\hline Macedonia & 0 & 0 & 1 & 1 \\
\hline \multirow[t]{2}{*}{ Albania } & 0 & 0 & 2 & 2 \\
\hline & 7 & 6 & 92 & 105 \\
\hline
\end{tabular}

Source: own drafting

Source of data in the table: www.citypopulation.de 
From a different point of view the whole region represents a population number of 128,7 million (www.citypopulation.de, 2015), and an economic weight of 1709,2 billion USD nominal GDP (IMF WEO, October 2015) which is already a significant weight for the global market, and specifically for advanced producer services. In the following I explain the studied data and its occurrence in the Central European space.

Table 2 Advanced producer services of research sample

\begin{tabular}{|c|c|c|c|c|c|}
\hline & Consultancy company & Seat & & Consultancy company & Seat \\
\hline 1 & A Beam Consulting & Asia & 31 & Kurt Salmon & Europe/ USA \\
\hline 2 & AT Kearney & USA & 32 & L.E.K.Consulting & Europe \\
\hline 3 & Accenture & Europe/ USA & 33 & Logica & Europe \\
\hline 4 & AlixPartners LLP & USA & 34 & KPMG & Europe \\
\hline 5 & Altran Technologies & Europe & 35 & RSM US LLP & USA \\
\hline 6 & Arthur D. Little & Europe & 36 & McKinsey \& Company & USA \\
\hline 7 & Avasant LLC & USA & 37 & Mercer, LLC & USA \\
\hline 8 & Bain \& Company & USA & 38 & Mott MacDonald Limited & Europe \\
\hline 9 & BDO International & Europe & 39 & Navigant Consulting & USA \\
\hline 10 & BearingPoint & Europe & 40 & Oliver Wyman & USA \\
\hline 11 & Berkeley Research Group LLC & USA & 41 & PA Consulting Group Ltd. & Europe \\
\hline 12 & The Boston Consulting Group & USA & 42 & $\mathrm{PwC}$ & Europe \\
\hline 13 & Capco (Subsidiary of FIS) & Europe & 43 & Roland Berger & Europe \\
\hline 14 & Cap Gemini S.A & Europe & 44 & Simon-Kucher \& Partners & Europe \\
\hline 15 & CGI & Canada & 45 & Strategy\& & USA \\
\hline 16 & Cognizant Solutions & USA & 46 & Tata Consultancy Service & Asia \\
\hline 17 & Computer Sciences Corporation & USA & 47 & Tefen Management Consulting & Asia \\
\hline 18 & CEB & USA & 48 & Towers Watson \& Co. & USA \\
\hline 19 & Deloitte Touche Tohmatsu Limited & Europe/ USA & 49 & WS Atkins plc & Europe \\
\hline 20 & BAE Systems Applied Intelligence & Europe & 50 & Slalom Consulting & USA \\
\hline 21 & Ernst \& Young & Europe/ USA & 51 & IBM Global Business Services & USA \\
\hline 22 & FTI Consulting & USA & 52 & The Parthenon Group & USA \\
\hline 23 & Grant Thornton International Ltd & Europe & 53 & Alvarez\&Marsal & USA \\
\hline 24 & Hay Group & USA & 54 & NERA Economic Consulting & USA \\
\hline 25 & HCL AXON & Europe & 55 & ZS Associates & USA \\
\hline 26 & Hewitt Associates & USA & 56 & CRA International & USA \\
\hline 27 & Hitachi Consulting Corporation & USA & 57 & Gallup Consulting & USA \\
\hline 28 & Horváth \& Partners & Europe & 58 & AON Consulting Worldwide & USA \\
\hline 29 & HP Enterprise Services & USA & 59 & Cornerstone Research & USA \\
\hline \multirow[t]{2}{*}{30} & Huron Consulting Group Inc. & USA & 60 & Analyses Group & USA \\
\hline & & & 61 & Milliman & USA \\
\hline
\end{tabular}

Source: own drafting

Source of seat: website of consultancy companies 
The data used is from data available on websites of consulting companies. Data comprise the seat of the company, number of consultants employed, number of offices globally, and presence worldwide, and presence specifically in Central European cities.

Among consultancy companies three types are to be identified: strategic, full service and boutique types. Strategic consultancies offer services related to the strategic direction of the companies, usually with global presence, and international office network. The full service providers are global consultancies with a wide-range office network. Boutique consultancies focus either on a specific sector, or a very specialized segmented service. These consultancies have a smaller number, but globally acting office network. Boutique firms work with a smaller number of consultants, about 200 people, strategic firms work with $1000-5000$ consultants, while full-service providers have generally more than 80.000 employees.

43 advanced producer services have offices in Central Europe out of the examined 60, which is $72 \%$. This ratio is also an index for the weight of the Central European region regarding the location strategies of the multinational business consultancies in relation to the large regions in the world.

Half of the examined companies have their seats in Europe, the other half in the USA, and only three companies in the sample represent Asia, and four service providers have equal seats in Europe and USA.

The number of employees is above 1000 with the exception of five companies, about one third of the examined companies have an employee number between $1000-10.000$, one-third has $10.000-90.000$ consultants, and nine service providers have $100.000-350.000$ employees.

Regarding the size of the network, $40 \%$ of the companies have 20 - 90 offices globally, another $40 \%$ has more than 100 , and in case of 20\%, $500-700$ offices operate around the world. Regarding their presence in a number of countries, nine service providers have offices in $100-150$ countries, and these companies have also the highest presence in Central Europe. In case of the other examined companies about half - half have offices in $20-40$, respectively 40 - 60 countries, here no linearity can be identified between global and Central European presence.

Three aspects are discussed in the paper: the presence of the advance producer services in the cities, the weight of capital and other cities, and the relations to the urban networks, as a second aspect the consultancy companies and their location strategies, and as a third aspect the interrelatedness of the nine biggest capital cities, and their network based on the advanced producer services. 
When examining the presence of the advanced producer services from the view point of cities, capital cities arise, but not exclusively (Tab. 3.).

Table 3 Central European cities with presence of consultancy companies

\begin{tabular}{|c|c|c|c|c|}
\hline & City & $\begin{array}{l}\text { Number of } \\
\text { inhabitants }\end{array}$ & $\begin{array}{l}\text { Presence of consultancy } \\
\text { companies (number) }\end{array}$ & Position status \\
\hline 1 & Vienna & 1741246 & 28 & 0,459016393 \\
\hline 2 & Graz & 265778 & 8 & 0,131147541 \\
\hline 3 & Linz & 191501 & 7 & 0,114754098 \\
\hline 4 & Salzburg & 145871 & 6 & 0,098360656 \\
\hline 5 & Innsbruck & 122458 & 5 & 0,081967213 \\
\hline 6 & Klagenfurt & 95450 & 5 & 0,081967213 \\
\hline 7 & Sankt Pölten & 51926 & 1 & 0,016393443 \\
\hline 8 & Gratkorn & 7622 & 1 & 0,016393443 \\
\hline 9 & St Anton & 2426 & 1 & 0,016393443 \\
\hline 10 & Imst & 9827 & 1 & 0,016393443 \\
\hline 11 & Hohenems & 15659 & 2 & 0,032786885 \\
\hline 12 & Götzis & 11041 & 1 & 0,016393443 \\
\hline 13 & St Florian & 3608 & 1 & 0,016393443 \\
\hline 14 & Bregenz & 28696 & 1 & 0,016393443 \\
\hline 15 & Eisenstadt & 13101 & 1 & 0,016393443 \\
\hline 16 & Dornbirn & 47417 & 1 & 0,016393443 \\
\hline 17 & Budapest & 1735711 & 23 & 0,37704918 \\
\hline 18 & Györ & 128567 & 1 & 0,016393443 \\
\hline 19 & Prague & 1268796 & 24 & 0,393442623 \\
\hline 20 & Brno & 385913 & 8 & 0,131147541 \\
\hline 21 & Ostrava & 296224 & 5 & 0,081967213 \\
\hline 22 & Plzen & 170322 & 1 & 0,016393443 \\
\hline 23 & Liberec & 102754 & 2 & 0,032786885 \\
\hline 24 & Olomouc & 101003 & 2 & 0,032786885 \\
\hline 25 & Ceske Budejovice & 93715 & 1 & 0,016393443 \\
\hline 26 & Jihlava & 50075 & 2 & 0,032786885 \\
\hline 27 & Bratislava & 415589 & 16 & 0,262295082 \\
\hline 28 & Kosice & 240164 & 3 & 0,049180328 \\
\hline 29 & Poprad & 91352 & 1 & 0,016393443 \\
\hline 30 & Warsaw & 1715517 & 31 & 0,508196721 \\
\hline 31 & Krakow & 758334 & 10 & 0,163934426 \\
\hline 33 & Lódz & 718960 & 4 & 0,06557377 \\
\hline 33 & Wroclaw & 631188 & 11 & 0,180327869 \\
\hline 34 & Poznan & 550742 & 9 & 0,147540984 \\
\hline 35 & Gdansk & 460427 & 3 & 0,049180328 \\
\hline 36 & Szczecin & 408913 & 2 & 0,032786885 \\
\hline
\end{tabular}


Table 3 (Continued)

\begin{tabular}{|c|c|c|c|c|}
\hline 37 & Katowice & 307233 & 7 & 0,114754098 \\
\hline 38 & Torun & 204299 & 1 & 0,016393443 \\
\hline 39 & Bucharest & 1883425 & 22 & 0,360655738 \\
\hline 40 & Cluj Napoca & 324576 & 5 & 0,081967213 \\
\hline 41 & Timisoara & 319279 & 5 & 0,081967213 \\
\hline 42 & Iasi & 290422 & 3 & 0,049180328 \\
\hline 43 & Constanta & 283872 & 2 & 0,032786885 \\
\hline 44 & Sibiu & 147245 & 1 & 0,016393443 \\
\hline 45 & Sofia & 1212935 & 12 & 0,196721311 \\
\hline 46 & Varna & 334688 & 2 & 0,032786885 \\
\hline 47 & Ljubljana & 274826 & 9 & 0,147540984 \\
\hline 48 & Zagreb & 688163 & 11 & 0,180327869 \\
\hline 49 & Koprovnica & 30854 & 1 & 0,016393443 \\
\hline 50 & Sarajevo & 393000 & 7 & 0,114754098 \\
\hline 51 & Banja Luka & 164200 & 1 & 0,016393443 \\
\hline 52 & Belgrade & 1166763 & 12 & 0,196721311 \\
\hline 53 & Pristina & 145149 & 3 & 0,049180328 \\
\hline 54 & Podgorica & 150977 & 3 & 0,049180328 \\
\hline 55 & Skopje & 491000 & 5 & 0,081967213 \\
\hline
\end{tabular}

Source: own drafting

Source of data on population: www.citypopulation.de, 2011.

Source of data for presence in Central Europe: website of consultancy companies

The examined 60 service providers have offices in altogether 55 cities in Central Europe. Warsaw has the highest number of presence with 31 , Vienna follows it with $28,-22$ companies have offices in both cities. This shows that the weight of Vienna is not overwhelming, it has the second position after Warsaw. On the second level Prague has 24, Budapest 23 and Bucharest 22 offices. Sofia, Belgrade and Zagreb have only offices of advanced producer services which have also offices in the five above mentioned cities. Ljubljana is a more developed country based on economic indicators, however it has the lowest presence among the nine capital cities due to its market size.

There are three consultancy companies in the examined sample in Central Europe that have no seats in either of the four capitals Vienna, Warsaw, Prague and Budapest, these companies have offices in different cities in Poland.

Location strategies of the advanced producer services reflect the urban network of each country. According to city locations in countries with a polycentric urban network - Poland, Austria and Czech Republic - other cities than capital also occur as sites for consultancy companies. However it's Austria within this group where presence of consultancy company in 
cities with less than 50.000 inhabitants also occurs. In these cases presence of a multinational production company underlines site location.

Traditionally monocentric country is Hungary (the most monocentric along with Serbia based on this study) with one company in Györ besides Budapest, Slovakia where Kosice and Poprad are on the map, and Bulgaria where Varna occurs marginally besides the capital cities as location sites. The capitals of the small West-Balkan cities also have locations, basically due to the fragmented and rather isolated urban networks of the region's countries.

$73 \%$ of the cities have more than 100.000 inhabitants, the ratio is rather due to Austria where 11 cities ( $20 \%$ of the examined sample) serve as location sites for consultancy companies with a population below 100.000. Besides, two Czech, one Croatian and one Slovak city represents cities with less than 100.000 inhabitants.

By taking out cities with only one location of consultancy company out of the sample, 37 examined cities remain. The decrease affects Austria most, only 6 cities remain where more than one consultancy company has a location, and among the six only Klagenfurt's inhabitant number is below 100.000, however approaches it. It is only Hungary - besides the West Balkan countries - where only the capital is involved from this point of view.

Location strategy is an important part of multinational companies' corporate strategies. Factors like the number of countries where they show presence, number of offices and resource allocation define their operation and profitability. The most important location factor for the advanced producer services is the location of multinational production companies that outsource majority of strategic functions. Geographical closeness to the general multinational companies ensures the market for consultancy companies. Strategies of the advanced producer services differ regarding number of offices and geographical scope of their offices. Thus different consultancy companies define criteria of closeness differently, and based on it they show denser or sparser presence in a larger region. Taking it globally, the first level of decision is the presence in a large region, like Western Europe, Central Europe, Middle East, Far East, etc. The second level decision is what capacities, resources they allocate on these large regions, and accordingly they position cities. If a decision is met on the number of cities then the advanced producer service provider weighs further aspects, like number of multinational companies, economic indices, and infrastructure of city including communication infrastructure, skilled labour, and density of population.

By studying the data from the aspect of consultancy companies, four groups emerge based on their location strategies (Tab. 4.). 
Table 4 Location strategies of consultancy companies

\begin{tabular}{|c|c|c|c|c|}
\hline & Consultancy company & $\begin{array}{c}\text { Number of } \\
\text { offices } \\
\text { globally }\end{array}$ & $\begin{array}{l}\text { Number of } \\
\text { countries } \\
\text { globally with } \\
\text { presence }\end{array}$ & $\begin{array}{l}\text { Number of cities } \\
\text { with presence in } \\
\text { Central Europe }\end{array}$ \\
\hline 1 & Bain \& Company & 53 & 34 & 1 \\
\hline 2 & Capco (Subsidiary of FIS) & 25 & & 1 \\
\hline 3 & BAE Systems Applied Intelligence & 33 & & 1 \\
\hline 4 & HCL AXON & & 18 & 1 \\
\hline 5 & L.E.K.Consulting & 21 & 14 & 1 \\
\hline 6 & $\begin{array}{c}\text { Oliver Wyman (Subsidiary of Marsh } \\
\text { \& McLennan) }\end{array}$ & 50 & 25 & 1 \\
\hline 7 & Alvarez\&Marsal & 45 & 18 & 2 \\
\hline 8 & Gallup Consulting & 30 & 20 & 2 \\
\hline 9 & Milliman & 60 & 24 & 2 \\
\hline 10 & Mercer, LLC & 180 & 40 & 2 \\
\hline 11 & Cognizant Solutions & 70 & 32 & 2 \\
\hline 12 & Arthur D. Little & 30 & 26 & 2 \\
\hline 13 & Simon-Kucher \& Partners & 29 & 22 & 2 \\
\hline 14 & Strategy\& & 57 & & 2 \\
\hline 15 & Tefen Management Consulting & 8 & & 2 \\
\hline 16 & Towers Watson \& Co. & 113 & 35 & 2 \\
\hline 17 & Tata Consultancy Service & 230 & 46 & 3 \\
\hline 18 & Accenture & 186 & 56 & 3 \\
\hline 19 & Altran Technologies & 118 & & 3 \\
\hline 20 & Horváth \& Partners & 13 & 6 & 3 \\
\hline 21 & The Boston Consulting Group & 80 & 46 & 4 \\
\hline 22 & BearingPoint & 64 & 20 & 6 \\
\hline 23 & Roland Berger & 50 & 36 & 6 \\
\hline 24 & AT Kearney & 61 & 40 & 6 \\
\hline 25 & Hay Group & 87 & 49 & 6 \\
\hline 26 & McKinsey \& Company & 108 & 60 & 7 \\
\hline 27 & CGI & 261 & 36 & 8 \\
\hline 28 & Logica & & 36 & 8 \\
\hline 29 & Mott MacDonald Limited & 180 & 50 & 8 \\
\hline 30 & Cap Gemini S.A & 205 & 44 & 10 \\
\hline 31 & IBM Global Business Services & 300 & 170 & 11 \\
\hline 32 & Computer Sciences Corporation & & 60 & 13 \\
\hline 33 & RSM US LLP & 110 & 73 & 13 \\
\hline 34 & HP Enterprise Services & & & 15 \\
\hline 35 & Grant Thornton International Ltd & 725 & 130 & 20 \\
\hline 36 & Hewitt Associates & & 135 & 24 \\
\hline 37 & AON Consulting Worldwide & 500 & 120 & 24 \\
\hline 38 & BDO International & 1450 & 151 & 26 \\
\hline
\end{tabular}


Table 4 (Continued)

\begin{tabular}{|c|c|c|c|c|}
\hline 39 & Deloitte Touche Tohmatsu Limited & & 100 & 28 \\
\hline 40 & Ernst \& Young & 700 & 150 & 28 \\
\hline 41 & KPMG & 700 & 156 & 28 \\
\hline 42 & PwC & 756 & 157 & 37 \\
\hline
\end{tabular}

Source: own drafting

Source of data in the table: websites of consultancy companies

There are six service providers with presence only in one country, these are either boutique firms, or such service providers that consider Central Europe as one macro-region, and offering presence only on this macro-regional level. They characteristically have $20-50$ offices globally, and concentrate their resources.

The second group comprises consultancy companies which show $2-4$ presence in the region. The majority is strategic firms but not exclusively, we can find full service companies as well. A great dispersion can be seen regarding their global presence, the number of their offices varies between $10-230$, and their country presence is between $18-56$.

The consultancy companies in the third group have offices in $6-15$ cities in Central Europe, both strategic and full service companies are represented. Characteristically they work with $60-300$ offices, have a presence in $20-70$ countries, however there is an outlier data with a presence in 170 countries. As a contrary to the previous group, the number of global offices of consultancy companies in this group is in correlation with the number of offices in the Central European region.

The service provider companies in the fourth group apply the strategy of overall presence, they show a high, $20-37$ presence in the region. These are mainly full service companies, their strategy is direct market access. These are the companies that characteristically have offices in the West-Balkan countries as well. These companies have globally an average of 700 offices and an average presence in $130-150$ countries. These companies have significant resources and they offer coverage with local presence on the market.

\section{CONCLUSION}

As already discussed before, Warsaw shows the biggest number of presence with 31 companies, Vienna follows with 28 presences. By studying the data it is only the four capital cities, Vienna, Prague, Warsaw and Budapest that are regarded as important locations globally. The four capital cities have a relatively high number of overlapping presence, however it can be seen that consultancy companies decide on presence in these cities on their own right. The conclusion (Tab. 5.) arises that only the mentioned four capital cities are 
competitive on a global level, the presence of consultancy companies in other capital cities in the region is related to the strategy of market presence.

Regarding the position of Bratislava, all companies with an office have also one in Prague, which identifies Bratislava as a secondary location due to direct market access. It is also underlined by the fact that not all companies have an office in Bratislava who has one in Prague. All companies having an office in Bratislava have an office also in Warsaw, so there is a strong correlation not only with Prague but also with Warsaw.

Regarding the position of Bucharest, it shows a high correlation with Prague and Budapest, but cannot prove as an independent location factor which is a prerequisite for Bucharest being a competitive site together with the four mentioned capitals.

Sofia, Belgrade, Zagreb, Ljubljana have only offices of consultancy companies that are present in the four first level capital cities. Sofia and Belgrade shows the same presence structure. Zagreb shows a strong correlation with Bucharest, all companies present in Zagreb, are also present in Bucharest.

Table 5 Matrix of cities: overlapping presence of consultancy companies

\begin{tabular}{|c|c|c|c|c|c|c|c|c|c|c|}
\hline & Vienna & Budapest & Prague & Bratislava & Warsaw & Bucharest & Sofia & Zagreb & Belgrade & Ljubljana \\
\hline Vienna & 28 & & & & & & & & & \\
\hline Budapest & 20 & 23 & & & & & & & & \\
\hline Prague & 20 & 21 & 24 & & & & & & & \\
\hline Bratislava & 14 & 16 & 16 & 16 & & & & & & \\
\hline Warsaw & 22 & 21 & 21 & 16 & 31 & & & & & \\
\hline Bucharest & 18 & 18 & 22 & 14 & 21 & 22 & & & & \\
\hline Sofia & 11 & 12 & 12 & 11 & 12 & 12 & 12 & & & \\
\hline Zagreb & 11 & 11 & 11 & 10 & 11 & 11 & 9 & 11 & & \\
\hline Belgrade & 11 & 12 & 12 & 11 & 12 & 12 & 12 & 9 & 12 & 8 \\
\hline Ljubljana & 9 & 9 & 9 & 8 & 9 & 9 & 8 & 8 & 8 & 9 \\
\hline
\end{tabular}

Source: own drafting

Source of data in the table: websites of consultancy companies

The paper uses only one indicator, the location strategy of advanced producer services in the Central European region, and the conclusion can be drawn that this factor shows the same results as other researches examining the economically leading cities in the region becoming integrated into the global urban structure. Advanced producer services as indicator of gravity centers in an urban network have a twofold role: they reflect the complex economic relations of the region on the one hand, that is, advanced producer services choose only locations with high economic potential. On the other hand it can also strengthen the results of national urban 
policies: advanced producer services can only be found in cities which have at least regional, in some cases a global role. Business service providers concentrate their capacities geographically, and they cover the market from a certain location. The geographical scope of coverage depends on whether it is a full service, a strategically oriented or a boutique type of company. If a critical level of economic potential is at stake in a city, it becomes a potential location for a business service provider, which further strengthens its regional economic role.

A decisive factor is that the Central European urban network is fragmented, it is not an integrated urban network. Further on small countries with cities with low population number is characteristic for the region with the exception of Poland. From this aspect it is even a more emphasized question what happens with the Central European urban structure, how far it can be integrated to global structures, and what will be the new peripheries in this region. Advanced producer services reflect the type of urban structure in a country clearly. If monocentric structure became resilient, and monocentricity resolved, and cooperation among geographically linked cities in neighbouring countries strengthened, location strategies of advanced producer services would adjust to it. Here it might be concluded that a more intensive cooperation among national urban structures could contribute to the strengthening of the economic weight of the macro-region thus attracting more advanced producer services. Presently role of cities cannot outreach borders.

According to the findings, as a result of the location strategies of full service companies all countries in the research space are on the map of advanced producer services. This fact indicates that no regions in the territory is excluded, which is highly important in the future development potentials of the Central European space. However the embeddedness of different sub-state regions is very different. Apart from the four already well-connected capitals (Warsaw, Vienna, Prague, Budapest), the integration of the Central European urban structure is mainly dependant on the location strategies of the strategy type of advanced producer services.

\section{REFERENCES}

Alderson, A.S., Beckfield, J., \& Sprague-Jones, J. (2010). Intercity relations and globalisation: the evolution of the global urban hierarchy, 1981 - 2007. Urban Studies, 47 (9), 1899-1923.

De Vos, A., Derudder, B., \& Witlox, F. (2012). Global city/ World city. In Derudder B., Hoyler M., Taylor P.J., Witlox F. (eds), International Handbook of Globalization and World Cities (pp. 73-82). Cheltenham, UK: Edward Elgar 
Derudder, B., Hoyler M., Taylor P.J., \& Witlox F. (eds) (2012). International Handbook of Globalization and World Cities, Cheltenham, UK, Edward Elgar

European Commission (1999). European Spatial Development Perspective, ESDP. Luxembourg: Office for Official Publications of the European Communities

European Commission (2007). Leipzig Charter. Luxembourg: Office for Official Publications of the European Communities, http://ec.europa.eu/regional_policy/en/policy/themes /urban-development/agenda/, downloaded on March 22016.

Friedmann, J, \& Wolff, G. (1982). World City Formation. An Agenda for Research and Action. International Journal of Urban and Regional Research, 6 (2) p. 319.

Friedmann, J. (1986). The World City Hypothesis. Development and Change, 17(1), p. 69-83.

Hall, P (1966). The World Cities. London: Weidenfeld and Nicolson.

Hall, P. (1990). Cities of Tomorrow. An Intellectual History of Urban Planning and Design in the Twentieth Century. New York, Basil Blackwell.

International Monetary Fund World Economic Outlook, nominal GDP, October 2015, http://statisticstimes.com/economy/countries-by-projected-gdp.php, downloaded on February 25, 2016.

Kunzmann, K. R., \& Wegener M. (1996). New Spatial Patterns of European Urbanisation. In: Pumain, D., Saint-Julien, T., eds.: Urban Networks in Europe, pp. 7-17.. Paris: John Libbey. http://www.spiekermann-wegener.de/pub/pdf/MWKK_Saint_Cloud_1996.pdf, downloaded on January 13, 2016.

Pounds, N. J. G. (2003). Európa történeti földrajza. Budapest, Osiris Kiadó.

Sassen, S. (1991). The Global City: New York, London, Tokyo. Princeton University Press.

Sassen, S. (2000). The Global City: Strategic Site/New Frontier. American Studies, 41:2/3 pp. 79-95.

Sassen, S. (2005). The Global City: introducing a Concept. Brown Journal of World Affairs, XI (2) pp.27-43

Sassen, S. (2008). The Global City. Research Gate. https://www.researchgate.net/publication /228007266, downloaded on March 22016.

Taylor, P. J. (2004). World city network. A Global Urban Analyses. London: Routledge.

Taylor, P. J., Ni, P., Derudder, B., Hoyler, M., Huang, J., Witlox, F. (eds) (2011). Global Urban Analyses: A Survey of Cities in Globalization. London, Earthscan.

Taylor, P. J. (2012). Interlocking network model. In: Derudder, B., Hoyler, M., Taylor, P.J., Witlox, F. (eds) (2012). International Handbook of Globalization and World Cities, (pp. 51-63). Cheltenham, UK, Edward Elgar.

Taylor, P. J., Derudder, B., Hoyler, M., Witlox, F. (2012). Advanced producer servicing networks of world cities. In: Derudder B., Hoyler M., Taylor P.J., Witlox F. (eds) International Handbook of Globalization and World Cities, (pp. 135-145). Cheltenham, UK, Edward Elgar

www.citypopulation.de 